\title{
Risking Border Instability: the Russian-Estonian Case
}

\author{
Pierre Jolicoeur Frederic Labarre \\ https://doi.org/10.46272/2587-8476-2020-11-3-113-128
}

\begin{abstract}
In international relations, the last three decades have been marked by national and institutional fragmentation. The fate of Yugoslavia and the Soviet Union, and the regrettable way that events played out (especially in the former case), could befall other federative entities as well. Canada and Belgium come to mind, as do countries like Spain, all of which effectively function as federations. However, while federations usually have dispute settlement and mechanisms for secession embedded in their constitutions, sub-constitutive territories are often excluded from such considerations. What territories such as Kosovo, Sandjak, Abkhazia, South Ossetia, etc. have in common is that they share a desire for independence from their parent country. However, achiveing independence would present risks to the territorial integrity of other countries (what can be termed the domino principle), as well as risks to the endurance of flexible international law.

The cases we have alluded to above culminated in the Crimean crisis.

The problems between Estonia and the Russian Federation stem from the choice of precedent and founding text on which to base the former's renewed independence. While Estonia was founded on the basis of the 1920 Tartu Peace Treaty that put an end to the country's War of Independence, its experience as a Soviet Republic added another legislative filter in the form

of the 1977 Constitution of the Soviet Union. However, the principle of uti possidetis had evolved to apply to more than cases of colonialism. Thus, when Estonia seceded from the USSR with the borders it had been since 1945, it was doing so under the principle of uti possidetis. The current dispute stems from the fact that the Estonian political elite seek to have the 1920 Tartu Peace Treaty recognized as the foundational document for the country's renewed independence. Under the Treaty, Estonian sovereignty applied over a much larger territory. By insisting that any new border arrangement with Russia be based on that Treaty, Estonia is invalidating the principle of uti possidetis and the validity of the Constitution of the Soviet Union as a vehicle for independence. It implies a latent Article 5 situation between NATO and Russia, and threatens the legitimacy of other post-Soviet secessions.
\end{abstract}

\section{KEYWORDS}

Uti possidetis, Crimea, Ukraine, Estonia, Constitution of the Soviet Union, Tartu Peace Treaty 


\section{Introduction}

On 19 November 2019, H. Polluaas, President of the Estonian Riigikogu (parliament) and member of the Eesti Konservatiivne Rahvaerakond (Conservative People's Party of Estonia, EKRE) suggested that the Russian Federation should return the portion of territory east of the Narva River and Petseri to Estonian sovereignty, as called for by the treaty signed between independent Estonia and the then nascent Soviet Union in the city of Tartu, in 1920.

Such a statement poses many policy problems. First, it was uttered at a time when NATO forces deployed in the Baltic States at the request of Baltic governments were attempting to maintain a fragile deterrent against Russia. Second, tensions between the opposing forces on the contact line in Donbass were dissipating, as, by November 2019, units there had begun a partial withdrawal under OSCE supervision. Third, Polluaas' musings are contrary to the principle encapsulated by Article 2 of the North Atlantic Treaty requiring Alliance members to practice peaceful and friendly international relations.

More alarmingly, however, this statement was the latest example of the erosion of international law, on which small powers like Estonia rely for their security, and the predictability of their relations with neighbours. Perhaps this is why President of the Russian Federation V. Putin suggested in a recent interview that, upon the dissolution of the USSR in 1991, the newly independent republics had made off with Russian lands.

NATO-Russia relations are tense at the best of times, and Polluaas' statement has become part and parcel of official Estonian policy. What has permitted this statement to be made now? A combination of factors provides a workable hypothesis. First, the decline of American influence and credibility acts as a double lever, encouraging border revisionism and redefinition from all sides with impunity. ${ }^{1}$ Second, the inability of sustaining the norms-based international system set up by the West in the wake of the Second World War has meant that the principle of uti possidetis, and respect for the 1977 Constitution of the Soviet Union, which together should make a peaceful, predictable and legitimate dissolution possible, is being called into question.

The first part of this article offers a brief review of the literature on the principle of uti possidetis as it has been applied historically and as an enduring principle of conflict management and state-building. Part 2 looks at how the Estonian Soviet Socialist Republic applied the principles discussed in part 1 to secure its exit from the Soviet Union on the basis of the 1977 Constitution and through the application of uti possidetis as a principle of conflict management when seceding from another entity. Part 3 considers how Estonia's insistence on having the Tartu Peace Treaty prevail over uti possidetis threatens international law and stability. The fourth part investigates how the erosion of American power has enabled smaller states to become risk-prone without having to face any consequences. 


\section{Uti Possidetis: a Review}

"Uti possidetis, ita possideatis" is an expression found in Roman law meaning that "as one uses, one shall possess." In other words, possession is derived by use. The application and respect of this principle has provided the international community with an objective doctrine to manage and prevent potential conflicts arising from postcolonial secessions. Not only has it helped international diplomacy navigate post-World War II decolonization in South America, Asia and Africa, but it was also used to support the dissolution of the Soviet Union.

Fittingly, the doctrine of uti possidetis is buttressed by the definition of what a "state" is according to the 1933 Montevideo Conventions on the Rights and Duties of States. ${ }^{1}$ Article 1 of the Montevideo Convention defines a state as possessing the following qualifications: "(a) A permanent population; (b) a defined territory; (c) government, and; (d) capacity to enter into relations with other states." A state may thus exist de facto and/or de jure. ${ }^{2}$ But a state is a state because there is a permanent population in a defined territory, over which a government exercises sovereignty. In addition, when it comes to matters of secession from a larger political construct national, imperial or colonial - the territorial legacy must be unambiguous. ${ }^{3}$ This characterization does not define the term "population" or how that territory and population should be administered by a corresponding authority. This, in effect, is the application of the doctrine of uti possidetis, i.e. to impose an administrative status quo which would preserve the inviolability of borders. The purpose was to prevent the independence (as in territorial integrity) and stability of new states from being endangered by fratricidal struggles, without having an impact on customary law. ${ }^{4}$ S. Lalonde has shown that, although the application of uti possidetis has evolved, its successful utilization in the case of Latin American was meant to be limited to that particular regional context. ${ }^{5}$

Uti possidetis is used by the international community to lock new states into their habitual borders; it is a sort of administrative status quo designed to ensure a peaceful transition from one status to the next. This characteristic makes the doctrine a useful tool for conflict prevention and management, but it does not follow that international law (and indeed international society) condones secessionism. On the contrary, the principles of territorial integrity will always have precedence over the rights of peoples to self-determination. ${ }^{6}$ Neither the Helsinki Final Act of 1975 nor the Charter of Paris of 1990 authorize secessionism; merely self-determination. Selfdetermination can be either internal or external, and while the latter effectively means secession (usually permitted owing to gross violations of a minority's human rights), internal self-determination can never be the object of uti possidetis, ${ }^{7}$ unless the national

1 Some readers will be alert to the fact that only states in North, Central and South America (except Canada) were the original signatories of this Convention. Nevertheless, the Montevideo Convention was absorbed by the cannon of international law in 1945 upon the creation of Article 102, paragraph 1 of the Charter of the United Nations and therefore applies universally.

2 Duursma 1996, 119; Fabry 2010, 1-2. See also Hensel et al. 2006.

3 Ghebrewebet 2006, 43.

Ibid., 86

Lalonde 2002, 55.

Saxer 1992, 635.

Lalonde 2002, 189-197. 
legislation devolves the right of a constitutive or administrative unit to secede. ${ }^{1}$ Whereas internal self-determination concerns the way peoples govern themselves, external self-determination concerns the status of that new arrangement, i.e. international recognition predicated upon independence.

The principle of uti possidetis threatened the territorial integrity of states, because now every conceivable groupuscule could invoke this principle to fragment an existing state, or even a new state that would have been recognized under that same principle of uti possidetis. Therefore, it was vital to limit the application of self-determination to peoples as opposed to nations, or ethnic groups and/or cultural minorities.

In order to protect the principle of territorial integrity, United Nations General Assembly Resolution 2625 (XXV) ("The Declaration on Principles of International Law concerning Friendly Relations and Co-operation among States") of 1970 sought to distinguish between central authority and colonial possessions, while at the same time extending the right of self-determination to all peoples (not just colonial peoples). Colonies can separate from the metropolitan power, but minorities thus created by this independence cannot necessarily separate from the newly independent state, and this principle cannot be advocated to fragment the metropolitan power. ${ }^{2}$ In other words, the principle of uti possidetis was protected by respect for territorial integrity while simultaneously being modified by the evolutionary nature of the concept of selfdetermination. $^{3}$ The recognition of such situations therefore becomes injurious to territorial integrity and self-determination, because it fragments a recognized political entity further by recognizing the will of a minority over that of the majority. ${ }^{4}$

The international community has always been very keen to elevate the principle of territorial integrity above that of self-determination, since uti possidetis manifested itself as if it were an application of international customary law, "once the colonial people has asserted its right to self-determination through the attainment of independent statehood [authors: external self-determination], the stability imperative reasserts itself." ${ }^{\prime 5}$ And so it is not surprising to see the Helsinki Final Act (1975) and the Charter of Paris (1990) prohibiting secession. Following that same logic, the USSR was declared to have collapsed through "dissolution" as opposed to "secession." Yet, J. Duursma refutes the utility of this distinction:

Considering the fact that the disruption of the territorial integrity of an existing state can be either partial or total, and that the same international rules apply to the either of those effects, it serves no legal purpose to distinguish between secession, dissolution, separation or disintegration. ${ }^{6}$

The continuing evolution of the concept of self-determination seems to bear witness to this conclusion. In 1970, the International Court of Justice allowed the term 
to be equated with independence by defining self-determination as a dynamic concept. $^{1}$

By 1993, the Vienna Declaration and Programme of Action had confirmed that self-determination was a right that applied to people "subjected to alien subjugation."2 The Human Rights Covenant, which extended the right of self-determination to all peoples, was careful not to define the meaning of "peoples," 3 thus shifting the meaning of the doctrine of uti possidetis from "internal" to "external" self-determination nearly without skipping a beat. S. Lalonde sustains the notion that uti possidetis cannot apply to internal borders. ${ }^{4}$ Unless, of course, the central authority devolves the right to secede to its administrative units based on mutual consent. ${ }^{5}$

If a secession leads to a total disruption of a state's territorial integrity and thus to a dissolution of the pre-existing State, international recognition of the newly established States will be given more easily than if a secession implies only a partial disruption of a State's territorial integrity. ${ }^{6}$

This means that the application of uti possidetis appears to be valid for minorities to secede on the territory they occupy within a larger political unit, the very outcome which the doctrine was designed to prevent. The application of the principle of uti possidetis to the dissolution of the USSR helped make the secession of constitutive republics peaceful because the 1977 Constitution provided the right to secede to all the constitutive republics, in addition to declaratory rights of sovereignty over their respective territories and borders as they stood at dissolution.

\section{The 1977 Constitution of the Soviet Union and the Constitutive Republics}

It is therefore the conjunction of the 1977 Constitution of the Soviet Union and the application of uti possidetis that ensured the peaceful dissolution of the USSR. This section explores the role played by the Constitution, which the Union Republics of Russia and Estonia helped draft. It should be stressed here that scholars generally agree that Soviet legislative habits never resembled those of the West - Party policy, not law, reigned supreme. ${ }^{7}$ Yet, even this statement requires qualification. According to T. Towe (writing in 1967), constitutional amendments usually follow policy changes implemented by the authorities. In the Soviet tradition, constitutional amendments required two-thirds of the votes to pass, but the Presidium of the Supreme Soviet "is empowered to decide such questions independently, subject to subsequent

4 Lalonde 2002, 189. Although Lalonde says that "uti possidetis does not itself provide any criteria for deciding which administrative units should benefit from international legal protection" (and therefore recognition) on p. 193.

5 Here the cases of the USSR and Czechoslovakia come to mind. Fabry 2010, 69; Ghebrewebet 2006, 97.

6 Duursma 1996, 96. Evidently, total disruption implies that there is no longer any central authority, or that fragmentation is a consequence of mutual agreement between the administrative units. This clearly applies to the Soviet case, but is emphatically rejected/denied in the Yugoslav case.

7 Towe 1967, 1257-1258. 
confirmation by the Supreme Soviet of the USSR."1 While constitutional drafting can be a very personal affair, once passed, the amendment applied to all Union Republics equally - even in the breach. ${ }^{2}$

The legal tradition of the Soviet Union is contradictory in nature. There is "one Soviet nation," but Article 72 of the Constitution still allows for secession. ${ }^{3}$ The big question motivating scholars at the time of the unveiling of the 1977 Constitution was whether continuity would prevail or whether the new legislation would be put into force effectively, especially with regard to Article 6, so that "all organisations of the Party operate within the Constitutional framework of the USSR." " This would apply not only to the Communist Party of the Soviet Union, but also to the organs and agencies of constitutive Union Republics as well, such as the Supreme Soviet of the Estonian Soviet Socialist Republic, and that of the Russian Soviet Federative Socialist Republic.

This is of crucial importance in view of what the 1977 Constitution stipulated with regards to the jurisdictional privileges of the Union and its Republics. For instance, Article 73, paragraph 2 basically codifies the granting of Crimea to the Ukrainian Soviet Socialist Republic, for it is within the jurisdiction of the USSR to determine the boundaries of the Union and approve the changes of boundaries between Union Republics. Even more pertinently, Article 76 states that a Union Republic "is a sovereign soviet socialist state that has united with other Soviet Republics in the Union of Soviet Socialist Republics. Outside the spheres listed in Article 73 of the Constitution of the USSR, a Union Republic exercises independent authority on its territory." This is a clear example of a figment of legislative fantasy that bore no relation to reality. But such inaccuracies nevertheless intermingle with fact: Article 77 states (correctly) that "Union Republics take part in decision-making in the Supreme Soviet of the USSR, the Presidium of the Supreme Soviet of the USSR, the Government of the USSR, and other bodies of the Union of Soviet Socialist Republics." What is more, a serious attempt was made to include nationwide popular consultation in the drafting of the new Constitution. ${ }^{5}$ Whereas the sovereignty of Union Republics was admittedly partial at best, boundary alterations could be mutually agreed, as stipulated by Article 78.

It would be a serious exaggeration to conclude that the 1977 Constitution was meant to supersede the power of the Party. Nevertheless, the leading caste tried to adapt ideological irrealities with modernity. Thus, Communist ideological markers were dropped in favour of more "mainstream" national and state features in the Constitution. ${ }^{6}$ The law was not meant to rule until... the law started ruling. In a belated attempt to inject vitality into a gerontocratic system, M. Gorbachev launched a series of constitutional amendments designed to open up elections to diversity and plurality. ${ }^{7}$ The legitimacy of those changes were not visible at the time, or if they were, they were taken with a healthy dose of suspicion. ${ }^{8}$

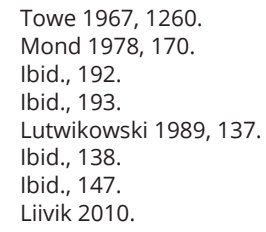


However, later research showed that the attempt not only worked, but it also consecrated the legitimacy of the secession for the Union Republics. In the case of the Estonian Soviet Socialist Republic, its Supreme Soviet rewrote its own constitution challenging the leading role of the Communist Party of the Soviet Union, in direct contravention of Article 78 of the 1977 Constitution. The Soviet authorities remained silent to this breach of "custom" and in doing so effetively accepted the widening jurisdiction of the constitutive Union Republics.

Second, the 1990 elections of the Supreme Soviet Estonian Soviet Socialist Republic were the first (and last) undertaken under M. Gorbachev's 1988 constitutional amendments. The first multi-candidate election in the Estonian Soviet Socialist Republic were demonstrably freer and more transparent, as the more credible level of participation suggests (71 percent, as opposed to the usual 99 percent). ${ }^{1}$ Elections were no longer a "charade". Rather, they were a means of revolution by law throughout the Soviet Union, and more particularly at level of the Union Republics. ${ }^{2}$

In effect, the law - specifically constitutional law - has been the foremost vector of the revolution that began in 1990 in the Soviet Union, allowing for the overthrow of the Soviet system and its transition towards a system that is not founded on single-party ideology. The real revolution in the USSR is a result of a revision of the Constitution - the repeal of Article 6 of the 1977 Constitution with regard to the leading role of the Communist Party. ${ }^{3}$

The Party tried to put the toothpaste back into the tube, but it was too little, too late. Subsequent secession laws were deemed contrary to the 1977 Constitution, ${ }^{4}$ and served only to consolidate secessionist sentiment. If the secession of the Baltic States was aimed at righting the wrongs of illegal annexation and recovering the independence and sovereignty they had won at the end of the First World War, then they could only do so with what the 1977 Constitution provided and within the practice of uti possidetis.

\section{How the Tartu Peace Treaty Enables the Erosion of Uti Possidetis}

Upon asserting its independence from the Soviet Union, Estonia quickly claimed continuity of the Tartu Peace Treaty of 2 February 1920, which the Russian government immediately countered. Estonia was unable to garner further diplomatic support to buttress its position. Factually speaking, therefore, the international community, and Russia in particular, seemed perfectly happy with the results: Estonia and Russia would separate from their larger entity, but keep to the territory they had administered for the longest period of time.

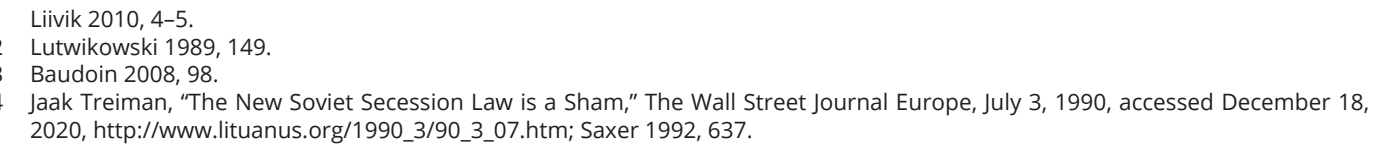


In 1995... [the] Estonian government gave in to the extent that it agreed that the 1944-1945 Soviet-created status quo would be transformed into the mutually recognised border between the Russian Federation and the Republic of Estonia. However, Estonia insisted that is considers the 1920 Tartu Peace Treaty to have been, and remain, continuously valid, with the exception of its borders being modified by the new border treaties essentially recognising the Soviet fait accompli of 1944-1945. ${ }^{1}$

International law views the Baltic States as successions rather than continuities because they were released from the Soviet Union, because their period of preannexation independence had been too brief (especially compared to the extended periods of domination under Danish, Russian and German rule), and because most of the powers of the former centres were turned over to them (as sufficiently demonstrated by O. Liivik and R. Lutwikowski, above). ${ }^{2}$ Thus, the matter of returning sovereignty to the Baltic countries based on their pre-USSR independence has weak foundations and "clouded by [...] more than fifty years of Soviet domination."3 Relying on the Tartu Peace Treaty is fraught with difficulties and other contradictions. ${ }^{4}$

In 2005, Russia and Estonia agreed to a border settlement (ERR). This border agreement was ratified by the Estonian Riigikogu on 20 June 2005. However, the text of the law on ratification (not the treaty itself) declared that ratification:

... [proceeded] from the legal continuity of the Republic of Estonia proclaimed on 24 February 1918, as it is established in the Constitution of the Republic of Estonia, in the 20 August 1991 decision of the Supreme Council (Soviet) of the Republic of Estonia "On the Independence of Estonia" and in the 7 October 1992 declaration of the Riigikogu "On the Restoration of the Constitutional State Power." [...] The declaration adopted by the Riigikogu in connection with the ratification of the border treaties goes on to say that the land border treaty concluded with Russia "partially changes the line of the state border established in Article III, para. 1 of the Tartu Peace Treaty of 2 February 1920, does not have impact on the rest of the (Tartu Peace) Treaty, and does not determine the treatment of other bilateral questions that are not connected to the border treaty." ${ }^{5}$

The Russian authorities reacted by rescinding their signature to the border treaty on 1 September 2005, arguing that the text of the Estonian law on ratification called

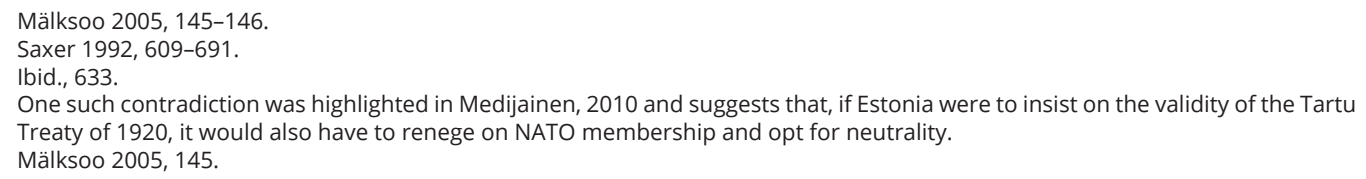


into question the chronological baseline of the negotiations - which had been the 1944 situation - thus leaving the possibility open that Estonia might one day make territorial claims against Russia in the future. ${ }^{1}$

Fast forward another decade to 18 February 2014 and the signing by Estonia and Russia of the border treaty (which is never ratified). ${ }^{2}$ Within a year, the newly elected Eesti Konservatiivne Rahvaerakond party had, when pressed to give its consent to the ratification of a new Russia-Estonia border treaty, started pushing for an additional preamble to the text of the agreement that was almost identical to that of the ratification law drawn up a decade earlier, with the only difference being to alter the line starting with "partially changes" to "in accordance with Article 122 of the Estonian Constitution." ${ }^{\prime 3}$ This preamble was thus added after the negotiations have been concluded. Predictably, the Russian authorities have refrained from ratifying the new border treaty.

The preamble was put forward by EKRE Deputy Chairman H. Polluaas, ostensibly because reference to the Tartu Peace Treaty of 1920 was necessary to solidify the philosophical and psychological bases for Estonia's claims to legal continuity. ${ }^{4}$ Otherwise, Polluaas added, there was no "political, economic or other reasons to sign the Estonian-Russian border treaty," suggesting that relying on the 1944-1945 border demarcations of the two former Soviet Socialist Republics (Russian and Estonian) was sufficient. ${ }^{5}$ In other words, H. Polluaas seemed to agree that an operative doctrine of uti possidetis provided a workable foundation for the two countries.

There was no way that Russia could accept the mention of the 1920 Tartu Peace Treaty being in this context. While the preamble appeared to accept the border modification that the 1944 position created for Article III of the Tartu Peace Treaty, reference to Article 122 of the Estonian Constitution re-introduced the sanctity of that very Article III indirectly, as "ratification of international treaties which alter the state borders of Estonia require a two-thirds majority of the membership of the Riigikogu." However, it could be argued that this is not an international, but rather a bilateral treaty. Taken this way, there is no disposition in the Estonian Constitution to modify the border bilaterally. Article III, para. 1 of the Tartu Peace Treaty of 1920, unless parts thereof are invalidated by a bilateral agreement, must take precedence.

And even if the Russia-Estonia border treaty of 2015 is deemed to be an international treaty, Article 123 of the Estonian Constitution intervenes by stating that the Republic of Estonia "shall not enter into international treaties which are in conflict with the Constitution." In other words, if Article 122 is mentioned, the entire notion of a preamble modifying Article III, para. 1 of the 1920 Tartu Peace Treaty could make a border treaty between Russia and Estonia unconstitutional.

If the issue were merely symbolic, the matter should still be acceptable to Russia. ${ }^{6}$ However, statements made by EKRE members since May 2019 indicate the contrary.

1 Mälksoo 2005, 145.

2 Markus Turovski, "Polluas on Border Treaty Sparks Reactions from Kremlin and State Duma," ERR, November 21, 2019, accessed December 12, 2020, https://news.err.ee/1005079/polluaas-on-border-treaty-sparks-reactions-from-kremlin-and-state-duma.

3 J. M. Laats, "EKRE Pushing for Treaty of Tartu Mention in Border Treaty," ERR, December 10, 2015, accessed December 14, 2020, https://news.err.ee/117354/ekre-pushing-for-treaty-of-tartu-mention-in-border-treaty. 
On 6 May, EKRE member R. Kaalep, who has been part of the new coalition since the 2019 Estonian legislative elections, said that the government had no intention of ratifying the treaty. ${ }^{1}$ Minister of Foreign Affairs $U$. Reinsalu (Fatherland Party) noted on the following day that the question of bringing ratification to a vote had not been a condition for forming the coalition. ${ }^{2}$ Then, on 9 May, EKRE leader and Minister of the Interior M. Helme expressed the view that "... ratification of the border treaty was contingent on Russia recognizing the much-earlier Tartu Peace Treaty of 1920, signed between the newly-independent Estonia and the fledgling Soviet Russian state." ${ }^{3}$

M. Helme argued that the territory granted to Estonia under the 1920 Tartu Peace Treaty was occupied in the same manner that Georgian and Ukrainian territory have been occupied since 2008 and 2014, respectively. ${ }^{4}$ Predictably, this drew sharp condemnation from Russia, which understood this as Estonia making a claim on its territory. ${ }^{5}$ The issue was no longer symbolic in nature, but material. In November, the agreement with Russia became contingent upon Estonia dropping what Ministry of Foreign Affairs of the Russian Federation spokesman S. Belyaev called "territorial claims on Russia."6 On November 20, President of the Estonian Riigikogu H. Polluaas (EKRE), speaker of the Riigikogu, was quoted by ERR as saying:

Estonia does not have any territorial claims against Russia. We do not want a single square meter of Russian soil. We just want ours returned. Russia has annexed ca. 5 percent of the territory of Estonia [...] De facto are Russia's illegal claims against Estonia that are in violation of international law. The annexation of Estonian territories is in no way different from the occupation and annexation of Crimea. One simply happened decades before the other. The EstoniaRussia border is fixed in the Treaty of Tartu that is included in the UN's list of valid international agreements. Those are the borders in which countries recognized Estonia's restoration of independence. The border treaty can only be taken forward insofar as it includes Russia recognizing the Treaty of Tartu and the border marked therein. ${ }^{7}$

According to Chairman of the Foreign Affairs Committee M. Mihkelson (Reform Party), the intention until today had been to abide by the uti possidetis principle,

1 Andrew Whyte, "Agreement in Place Not to Ratify Border Treaty Says Ruuben Kaalep," ERR, May 6, 2019, accessed December 14, 2020, https://news.err.ee/936832/agreement-in-place-not-to-ratify-border-treaty-says-ruuben-kaalep.

2 Andrew Whyte, "Foreign Minister: Estonia Cannot Back Down on Tartu Peace Treaty Principles," ERR, November 19, 2019, accessed December 14, 2020, https://news.err.ee/1004589/foreign-minister-estonia-cannot-back-down-on-tartu-peace-treaty-principles.

3 Andrew Whyte, "Prime Minister: We have to Be Realistic About Border Ratification," ERR, May 10, 2019, accessed December 14, 2020, https://news.err.ee/938396/prime-minister-we-have-to-be-realistic-about-border-ratification.

4 Andrew Whyte, "Russia Foreign Ministry, Embassy, Attack border treaty comments," ERR, May 16, 2019, accessed December 14, 2020, https://news.err.ee/939966/russian-foreign-ministry-embassy-attack-border-treaty-comments.

5 Ibid.

6 Andrew Whyte, "Russia Foreign Ministry, Embassy, Attack Border Treaty Comments," ERR, May 16, 2019, accessed December 15, 2020, https://news.err.ee/939966/russian-foreign-ministry-embassy-attack-border-treaty-comments.

7 Markus Turovski, "Polluas on Border Treaty Sparks Reactions from Kremlin and State Duma," ERR, November 21, 2019, accessed December 14, 2020, https://news.err.ee/1005079/polluaas-on-border-treaty-sparks-reactions-from-kremlin-and-state-duma. 
"without territorial claims from either side."1 M. Mihkelson confirms that this had been the foundation of the draft border treaty that had been agreed on 18 February $2014 .^{2}$ Yet the EKRE narrative is a response to Russia's recognition of Abkhazia and South Ossetia (breakaway Georgian regions following the Russo-Georgian War of 2008) and to Crimea's fusion with Russia. Both the Georgian and Ukrainian crises were inspired by the unilateral declaration of independence by Kosovo. ${ }^{3}$

This cascade of recognitions - from the recognition of Kosovo to the partial recognition of Crimea - invalidates the principle of uti possidetis, a fundamental norm of international law. Rather, Estonia-Russia relations, and, in a wider context, NATORussia relations, reflect typical tit-for-tat diplomacy and border revisionism claims. So it is no surprise that certain media outlets surmised that Putin accused the former Soviet Republics of "making off" with Russian lands after the dissolution of the Soviet Union. Putin made the comment during a documentary interview with P. Zarubin on 12 June 2020 which aired on 21 June 2020 for the multi-part Rossiya 1 documentary series entitled Russia. Putin. Kremlin. Few in the mainstream media latched onto those comments, save for UAWire, an online news platform of unknown reach, and K. Altynbayev from the Kazakh online news site CaravanSerai. K. Altynbayev in particular made the assumption that Putin was thus suggesting that these lands should be returned. Radio Free Europe/ Radio Liberty can be credited with more accurately stressing Mr. Putin's point, which was that when the USSR was created, the right to opt out was written into the original Declaration and Treaty on the Formation of the Union of Soviet Socialist Republics, but the procedure for implementing such a decision was not.

The treaty establishing the Soviet Union articulated the right to exit it but did not outline the procedure for doing so. ${ }^{4}$ So the question arises: what if a republic joined the Soviet Union but received a massive amount of Russian land that was ancestral, historic Russian territory and then decided to exit the Soviet Union? In that case, it should have left with what it brought - not take along the gifts from the Russian people. $^{5}$

Mr. Putin never mentioned that Russia might seek the return of territories, or that certain former Republics should give the "stolen" land back. Rather, he was stating that

1 Markus Turovski, "Polluas on Border Treaty Sparks Reactions from Kremlin and State Duma," ERR, November 21, 2019, accessed December 14, 2020, https://news.err.ee/1005079/polluaas-on-border-treaty-sparks-reactions-from-kremlin-and-state-duma.

2 Ibid.

3 Jolicoeur, Labarre 2014, 46.

4 According to Altynbayev, Putin is referring here to the 1922 Declaration and Treaty on the Formation of the Union of Soviet Socialist Republics, not the 1977 Constitution of the Soviet Union, which also allows republican separation. Kanat Altynbayev, "Putin's invented territorial claims on post-Soviet States draws ire of Kazakhs," Caravan Serai, June 29, 2020, accessed December 15, 2020, https://central.asia-news.com/en_GB/articles/cnmi_ca/features/2020/06/29/feature-01.

5 This section of the interview is available in Russian on YouTube as "'Podarki ot Russkogo Naroda' ('Gifts from the Russian People')," YouTube, June 21, 2020, accessed December 12, 2020, https://www.youtube.com/watch?v=GcNEb9VZvzw\&feature=youtu.be; Pavel Zarubin's documentary is the culmination of several interviews carried out between 18 September 2019 and 12 June 2020 on behalf of Channel Rossiya 1. See: "Rossiya 1," accessed December 12, 2020, https://russia.tv/brand/show/brand id/64871/. See also "Putin: Former Soviet Republics left USSR with Russian Lands," UAWire, June 22, 2020, accessed December 15, 2020, http://www.uawire.org/putin-former-soviet-republics-left-ussr-with-russian-lands; “Kremlin Denies Eyeing Territorial Claims after Putin's Comments in Documentary," Radio Free Europe/Radio Liberty, June 22, 2020, accessed December 15, 2020, https://www. rferl.org/a/kremlin-denies-eyeing-territorial-claims-after-putin-s-comments-in-documentary/30684797.html. 
such transfers should be carried out under some form of legal procedure precisely to avoid misunderstandings further down the road. This is what the 1977 Constitution of the Soviet Union and the practice of uti possidetis provided in the case of Estonian secession: recognition, but within the borders under that particular legal regime.

\section{How the Lost Hegemony of the United States Empowers Small States}

Another enabler of tension is the erosion of American hegemonic power. The worsening standoff between Estonia and Russia over the codification of the border has attracted regional media attention, but, apparently, no overt interest from NATO leaders. This is an ominous sign, for the implications of $\mathrm{H}$. Polluaas' statement (and of Estonian policy in general) regarding the validity of the 1920 Tartu Peace Treaty would mean that Russia is already occupying Estonian, and therefore NATO, territory. In other words, there is a latent Article 4 and Article 5 situation between Estonia and Russia. This should be of priority interest to major NATO powers for two reasons: first, they are the primary norm builders of the post-war and post-Cold War eras, and it is in their interests to uphold these norms. Second, it is the burden of major powers to discipline weaker NATO members to avoid drifting into war. ${ }^{1}$

Estonia has been able to avoid opprobrium from NATO's major powers ostensibly because of the declining influence of the United States in world affairs. This decline has made it impossible for the United States to assume the lead in order to maintain the international legal order.

As P. Kennedy reminds us, great power decline is empirically measurable. ${ }^{2}$ More recently, the Peter G. Peterson Foundation, which monitors US government spending and debt treatment has calculated that the US deficit will amount to a minimum of 1 trillion dollars per year over the next several years, and that the country's total debt will surpass 23 trillion USD in 2020. ${ }^{3}$ Evidently, much of this year's debt has been generated by counter-pandemic funding.

Since 2008, mainly owing to partisan divisions, the United States has been unable to pass a regular budget, proceeding instead with "continuing resolutions," which is tantamount to someone signing on to an ever-increasing credit margin. With no plan as to how to spend money, the most expeditious method to service the debt and reduce the deficit would be to cut spending, which would effectly reduce the administrative and even operational capacity of the country.

Evidence of such spending cuts have made the news recently, with the D. Trump administration furloughing between 50 and 70 percent of the workforce in the Citizenship and Immigration Services, ${ }^{4}$ the decision to withdraw American forces from Germany, ${ }^{5}$ and the US departure from the Syrian theater of operations, ${ }^{6}$ among

1 Wolfers 1962.

2 Kennedy 1988

3 "The Current Federal Defecit and Debt," Peter G. Petersen Foundation, November 2020, accessed December 15, 2020, https:// www.pgpf.org/the-current-federal-budget-deficit.

4 “Deputy Director for Policy Statement on USCIS Fiscal Outlook," USCIS, June 25, 2020, accesed December 14, 2020, https://www. uscis.gov/news/news-releases/deputy-director-policy-statement-uscis-fiscal-outlook.

5 "Donald Trump Approves Plan to pull 9500 Troops from Germany," Deutsche Welle, July 1, 2020, accessed December 14, 2020, https://www.dw.com/en/donald-trump-approves-plan-to-pull-9500-troops-from-germany/a-54006399.

6 Rhode 2019, 1-3. 
other fiscal news. The US commitment to sustaining NATO's Operation Reassurance in the Baltic States, which was launched in 2015, may already be seen as half-hearted US troops are deployed in Poland, not to the Baltic States.

In addition, the US withdrawal from world affairs has been compounded by the country's departure from the very norms that it had championed during the Cold War. The abrogation of the Treaty on the Non-Proliferation of Nuclear Weapons and the Treaty on Open Skies follows a trend that began in 2002 when the G. W. Bush administration pulled out of the Anti-Ballistic Missile Treaty, which was followed by Russia's exit from the Treaty on Conventional Armed Forces in Europe. It is doubtful that the recent election of J. Biden will reverse this trend in the short term.

The decline of American power also means a lot to NATO, as President of France E. Macron hinted in his now-famous November 2019 interview with The Economist ${ }^{1}$. Simply put, without the United States, NATO is clinically dead. What is more, France and Germany - the leading EU powers - are considering measures to make European defence more autonomous from US participation.

\section{Conclusion}

It is thus no surprise that Estonia might feel buoyed by the example provided by the two great powers, and that it is engaging in a kind of legal jettisoning of its own. It would seem that there is little to lose: with NATO troops on Estonian territory, this is the only form of deterrence from the West that Russia has to respect. Meanwhile, whatever policy Estonia may want to adopt to press its claim, the United States has put itself in a very delicate position to object.

The canon of international law exists to provide small states with the predictability they need to manage their relations in a way that outcomes (even if they are perceived to be unjust) may still have commonly held legitimacy. The border dispute between Russia and Estonia could be settled based on the latter's right to secede from the USSR with its 1945 borders as establised by the Constitution of the Soviet Union, and on the application of uti possidetis as permitted by international law. Instead, Estonia is now emphasizing the Tartu Peace Treaty of 1920. This argument, pushed to its logical conclusion, creates a territorial overlap between Estonia and Russia and is thus a latent source of trouble for NATO. More to the point, it threatens the principle of uti possidetis and the validity of the Constitution of the Soviet Union as it stood when other Union Republics seceded from the USSR.

The only reason why Estonia has been able to advance its position on the border issue is because international law has been eroding since at least 2008, and larger powers have set a negative example. Ironically, that very position, which is also a symptom of greater independence, may put the country at the mercy of its adversaries, if its Allies decide not to fulfill their guarantees. 


\section{СПИСОК ЛИТЕРАТУРЫ / REFERENCES}

Duursma, Jorri. Fragmentation and International Relations of Micro-States. Cambridge: Cambridge University Press, 1996.

Fabry, Mikulas. Recognizing States: International Society and the Establishment of New States Since 1776. Oxford: Oxford University Press, 2010.

Ghebrewebet, Helen. Identifying Units of Statehood and Determining International Boundaries: A Revised Look at the Doctrine of Uti Possidetis and the Principle of SelfDetermination. Frankfurt-am-Main: Peter Lang, 2006.

Hensel, Paul, Michael Allison, and Ahmed Khanani. Territorial Integrity Treaties, Uti Possidetis, and Armed Conflict over Territory. Paper presented at the 2006 Shambaugh Conference "Building Synergies: Institutions and Cooperation in World Politics". University of lowa, 13 October 2006. https://ir.uiowa.edu/cgi/viewcontent.c gi?article $=1028 \&$ context=shambaugh

Jolicoeur, Pierre, and Frédéric Labarre. "The Kosovo Model: A (Bad) Precedent for Conflict Management in the South Caucasus?" Connections 13, no. 3 (2014): 41-58.

Kennedy, Paul. The Rise and Fall of Great Powers. New York: Random House, 1988.

Lalonde, Suzanne. Determining Borders in Conflict: The Role of Uti Possidetis. Kingston: McGill/Queen's University Press, 2002.

Liivik, Olev. "Formation of the Supreme Soviet of the ESSR: Elections and Principles of Assembling." Institute of Historical Memory, 2010.

Lutwikowski, Rett R. "Constitution of the Soviet Unional Changes of the Glasnost Era: A Historical
Perspective." New York Law School Journal of International and Comparative Law, no. 2(10) (1989): 119-150.

Mälksoo, Lauri. "Which Continuity: The Tartu

Peace Treaty of 2 February 1920, the Estonian-Russian Border Treaties of 18 May 2005, and the Legal Debate of Estonia's Status in International Law." Juridica International, no. X (2005): 144-149.

Medijainen, Eero. "Article 5: The Permanent Neutrality in the Tartu Peace Treaty, 1920." Journal of Baltic Studies, no. 2(41) (2010): 201-214.

Mond, Georges H. "Les nouvelles constitutions de I'U.R.S.S. et la Chine comparées aux récentes lois fondamentales de la Pologne et de l'Albanie." Revue comparative Est-Ouest, no. 3(9) (1978): 169-194. [in French].

Rhode, Benjamin "The US Withdrawal from Syria." In International Institute for Strategic Studies - Strategic Comments, 1-3. January 31, 2019.

Saxer, Urs W. "The Transformation of the Soviet Union from Socialist Federation to a Community of Independent States." Loyola of Los Angeles International and Comparative Law Review, no. 14 (1992): 581-715.

Towe, Thomas E. "Fundamental Rights in the Soviet Union: A Comparative Approach." University of Pennsylvania Law Review, vol. 115 (1967): 1251-1274. Wolfers, Arnold. Discord and Collaboration.

Baltimore, MD: Johns Hopkins Prress, 1962.

Baudoin, Marie-Élisabeth. "Droit et révolution dans l'espace post-soviétique: Les lendemains de la révolution par le droit." Siècles, no. 27 (2008): 97-116. [in French].

\section{Authors}

Pierre Jolicoeur,

PhD, Royal Military College of Canada (Kingston), K7K 7B4,

PO Box 17000, Station Forces.

e-mail: pierre.jolicoeur@rmc.ca

Frederic Labarre,

PhD candidate, Royal Military College of Canada (Kingston), K7K 7B4,

PO Box 17000, Station Forces.

e-mail: frederic.labarre@rmc.ca

\section{Additional information}

Received: October 11, 2020. Accepted: December 16, 2020.

\section{Acknowledgments}

The authors would like to express their gratitude to the anonymous reviewers and editors, whose input greatly helped in focusing the argument and in improving the quality of the text.

\section{Disclosure statement}

No potential conflict of interest was reported by the authors.

\section{For citation}

Jolicoeur, Pierre, and Frederic Labarre.

"Risking Border Instability: the Russian-Estonian Case." Journal of International Analytics 11, no 3 (2020): 113-128. https://doi.org/10.46272/2587-8476-2020-11-3-113-128 


\title{
Риски пограничной нестабильности: российско-эстонский казус
}

\begin{abstract}
АННОТАЦИЯ
Международные отношения последние три десятилетия были отмечены тенденциями к национальной и институциональной фрагментации. Судьба Югославии и Советского Союза, а также печальный их исход (особенно в первом случае) может постигнуть и другие федеративные образования. Возникают примеры Канады и Бельгии, а также Испании, которые эффективно функционируют как федерации. Такие образования обычно имеют механизмы урегулирования споров, особенно вопросов отделения, заложенных в их конституциях, однако субконституционные территории часто исключаются из таких концептуальных рамок. Такие территории, как Косово, Санджак, Абхазия, Южная Осетия объединяет то, что они разделяют стремление к независимости от своей материнской страны. Однако достижение независимости будет представлять риски для территориальной целостности других стран (принцип домино), а также риски для устойчивости «гибкого» международного права. Те случаи, о которых мы говорили выше, завершились крымским кризисом. Проблемы между Эстонией и Российской Федерацией проистекают из выбора обоснования прецедента, на котором основываются приграничные территориальные вопросы независимой Эстонии. Хотя Эстония была основана на основе Тартуского мирного договора 1920 г., положившего конец войне за независимость страны, ее опыт как Советской

Республики добавил еще один законодательный фильтр в виде Конституции Советского Союза 1977 г. Однако принцип uti possidetis эволюционировал и стал применяться не только к случаям колониализма. Таким образом, когда Эстония отделилась от СССР в границах, существовавших с 1945 г., она делала это по принципу uti possidetis. Нынешний спор связан с тем, что эстонская политическая элита добивается признания Тартуского мирного договора 1920 г. в качестве основополагающего документа для восстановления независимости страны. Согласно Тартускому договору, эстонский суверенитет распространялся на гораздо большую территорию. Настаивая на том, чтобы любое новое пограничное соглашение с Россией основывалось на этом договоре, Эстония лишает законной силы принцип uti possidetis и действительность Конституции Советского Союза как средства достижения независимости. Это несет в себе риск задействования статьи 5 Североатлантического договора в отношениях между Россией и НАТО и угрожает легитимности других случаев сепаратизма на постсоветском пространстве.
\end{abstract}

\section{КЛЮЧЕВЫЕ СЛОВА}

Uti possidetis, Крым, Украина, Эстония, Конституция Советского Союза, Тартуский мирный договор

\author{
Сведения об авторах \\ Пьер Жоликер, \\ доктор философии, Королевский военный колледж Канады (Кингстон), К7К 7В4, \\ PO Box 17000. \\ e-mail: pierre.jolicoeur@rmc.ca \\ Фредерик Лабарр, \\ кандидат на получение степени доктора философии, \\ Королевский военный колледж Канады (Кингстон), К7К 7B4, \\ PO Box 17000. \\ e-mail: frederic.labarre@rmc.ca
}




\section{Дополнительная информация}

Поступила в редакцию: 11 октября 2020. Принята к публикации: 16 декабря 2020.

\section{Благодарности}

Авторы хотели бы выразить свою благодарность анонимным рецензентам и редакторам, чей вклад в значительной степени помог сосредоточить внимание на аргументации и улучшить качество текста.

\section{Конфликт интересов}

Авторы заявляют об отсутствии потенциального конфликта интересов.

\section{Цитирование}

Жоликер, П., Лабарр, Ф. Риски пограничной нестабильности:

российско-эстонский казус // Международная аналитика. - 2020. - Том 11 (3). - С. 113-128.

https://doi.org/10.46272/2587-8476-2020-11-3-113-128 